\title{
CULTURAL DEVELOPMENTS IN ELECTRONIC LAW ENFORCEMENT IN CRIMINAL ACTS OF THEORY IN INDONESIA
}

\author{
Yusep Mulyana \\ Law Faculty Universitas Pasundan, Indonesia \\ yusep.mulyana@unpas.ac.id
}

\begin{abstract}
The strength of proof of electronic evidence in law enforcement of criminal acts of terrorism in Indonesia is Law Number 11 of 2008 concerning Information and Electronic Transactions ("ITE Law") provides a legal basis regarding the legal force of electronic evidence and the formal and material requirements of electronic evidence so that can be accepted at trial. Electronic Evidence is Electronic Information and / or Electronic Documents that meet the formal requirements and material requirements stipulated in the ITE Law. Article 5 paragraph (1) of the ITE Law stipulates that Electronic Information and / or Electronic Documents and / or printouts are valid legal evidence. The implementation of the regulation of electronic evidence in law enforcement of criminal acts of terrorism in Indonesia is the use of evidence in the form of wiretaps and video recordings that were actually implemented in the 2002 Bali Bombing Case. In using this evidence the investigator referred to article 27 of the Government Regulation in lieu of the Law of the Republic of Indonesia No.1 of 2002 concerning the eradication of criminal acts of terrorism. Although inviting controversy, the prosecutor insisted that the reading of witness statements from Malaysia and Singapore that could not be present at the trial was valid because it was in accordance with the description of the evidence in the law. The same thing is regulated in the Law on Information and Electronic Transactions. Article 5 states that electronic information and / or printouts of electronic information are legal evidence and have legal legal consequences. Of course, electronic information is declared valid when using an electronic system in accordance with applicable laws and regulations.
\end{abstract}

\section{Keywords: Electronic Evidence, Law Enforcement, Criminal Acts of Terrorism.}

\section{Introduction}

Technological advances have infiltrated almost all aspects of life, including the law enforcement system. The presence of Law No. 11 of 2008 concerning Information and Electronic Transactions (UUITE) has introduced an electronic evidence regime. However, the regulation has not been balanced with the knowledge of law enforcement officials related to technological progress (Dellyana, 1988) (Hendy Sumadi, 2015)

Prosecutors and judges at this time may not have much theoretical knowledge and experience related to information technology. Maybe those who have the knowledge and experience about it are just investigators. Judges in Indonesia are more focused on the logical structure of a case. On the other hand, the lack of knowledge of law enforcers related to information technology has an impact on determining the validity of digital evidence. According to him, in Indonesia, especially in the regions, there are still many officials who do not want to enter the UUITE regime related to the provision of evidence.

Nevertheless, the validity of digital evidence is not the authority of the authorities. To determine a digital document can be legal evidence or does not require expertise and testimony. Therefore, expert testimony determines whether the evidence can meet formal and material requirements or not. Because experts can justify forensically. Expert who confirms whether the evidence is original or has changed. However, in addition to expert testimony, there must also be testimony from witnesses who support that indeed the evidence did not change anything.

Some countries such as China, Australia, Japan, and Singapore already have legal 
regulations that recognize electronic data as evidence. In Canada, for example, besides having a law of proof which accepts electronic data as evidence. Court practices complement it with procedures for how electronic evidence can be received in court. French state procedural law known as the Code de Procédure de Pénal which is based on the Counsil d'etat circular in 1998 (LOI 1998-2341- La Reconais des des evidence de dossiers et information informatiques) regarding the legality of electronic documents and information as legal evidence.

Unlike the arrangement in Malaysia, electronic evidence is included in the primary evidence category, namely evidence in the form of original documents presented in court, that is, all documents made in writing, or recorded on photo tapes, whether in the form of letters, books, journals, films, video, and so on. Parts of the document as long as it is original are considered primary evidence. In addition to primary evidence, there is also known secondary evidence which is only used as evidence, if primary evidence is lacking or inadequate (Insan Pribadi, 2018).

The classification of electronic evidence has not yet been fully accepted, even though on one hand in extraordinary crimes, such as corruption, serious human rights crimes, terrorism has difficult evidence. This is because these crimes are carried out neatly and systematically by using computers as a means to carry out these crimes, and the government realizes that the crime is an extraordinary crime, so it requires extraordinary handling as well (extraordinary measures ). Evidence that will lead to a criminal offense is electronic data that is in a computer or which is a print-out or in other forms in the form of a trace of a computer use activity (Alan M. Gahtan, 1999).

In 2016, precisely on January 14, 2016 at 10:40 WIB, when a series of explosions rocked the Sarinah crossing, Central Jakarta. According to a spokesman for the Republic of Indonesia National Police, the number of perpetrators of this unknown attack carrying grenades and firearms. According to media reports, 7 people were the perpetrators of the attacks.
The attack began when an explosion occurred in the Menara Cakrawala parking lot, in front of the Starbucks outlet at the Sarinah crossing at 10:40 WIB. The next three explosions occurred at a police station right at the Sarinah crossing, killing one civilian. While two other explosions took place inside a Starbucks outlet, killing one other civilian. After the explosion, several reports mentioned that there were three explosions in other areas, namely Cikini, Slipi and Kuningan, but the report was found to be a false report.

In responding to the use of the internet and other information technology by terrorists, the Indonesian Police Headquarters seeks to improve its handling by improving personnel, infrastructure, cooperation and coordination, socialization and training. The National Police are still experiencing limited human resources in terrorism cases in Indonesia (Hermawan Sulistyo, 2002)

Determination of the validity of digital evidence is very important, it is the duty of judges, prosecutors including legal counsel to ensure that the digital evidence submitted is truly original. Certainty must be obtained through a digital forensic process.

Digital evidence submitted in the court process must be valid. The validity must meet the elements according to regulations (lawful). Because the electronic evidence that has been difficult to obtain if it is not in accordance with the provisions in the regulations can be brought to pretrial.

That is why terrorism cases rarely provide evidence from the results of wiretapping. Therefore, evidence of the results of wiretapping is quite vulnerable. In a sense, the procedure of wiretapping in terrorism cases must be in accordance with the law (Benedict Dian Ariska Candra Sari, 2017).

In Law No. 1 of 2002 concerning the Eradication of Terrorism Criminal Acts, it is regulated that wiretapping is only allowed for the purpose of investigation and investigation. In addition, these actions must be carried out with the permission of the chairman of the court. In practice, police officers are often pressed for time to tap 
terrorists before conducting raids (Mamay Komariah, 2017).

Mastery of technology is often misused to commit a crime, among the various crimes that use technology in which there are new terrorist crimes namely cyber terrorism, handling cyber terrorism is different from handling conventional terrorism, the difference is the use of evidence in the form of electronic information.

In its development, the evidence as regulated in the Criminal Procedure Code can no longer accommodate the development of information technology, this has created new problems. One of them is the emergence of a new terrorist crime that is cyber terrorism, of course law enforcement efforts must not stop because of the absence of law governing the use of evidence and evidence in the form of electronic information in the settlement of legal events (Eka Lusyanti Marpaung, Mila Astuti, Ali Ibrahim, Analysis, 2017).

Acts of terrorism that occurred in Indonesia lately also seem to have not been completely resolved. This is one of the problems faced by the government at this time. Indonesia as a rule of law has an obligation to protect human dignity and dignity. Likewise in terms of protecting citizens from acts of terrorism. One of them is through law enforcement including efforts to create an appropriate legal product. This effort was realized by the government by issuing Government Regulation in Lieu of Law Number 1 of 2002, which was later approved by the Parliament to become Law Number 15 of 2003 concerning Eradication of Terrorism Criminal Acts. The need for this law is because the government realizes that the crime of terrorism is an extraordinary crime (extraordinary crime), so it requires extraordinary handling as well (extraordinary measure). Associated with criminal acts of terrorism, the regulation of evidence in the form of electronic information and electronic documents in this case the website is very necessary, the reason for acts of terrorism is more intense and justifies any means to be able to act.

Over the last few years crime has grown more rapidly and is troubling the public. The criminal act of terrorism has become a more destructive form of crime with a global scope. In this case the government has issued Government Regulation (Perpu) No. 1 of 2002 concerning the Eradication of the Criminal Acts of Terrorism. Then on April 4, 2003 the Perpu was passed into Law Number 15 of 2003 concerning the Eradication of Terrorism Crimes. But in reality there are still many evidences of criminal acts of terrorism that are not in accordance with existing rules, meaning that there are still many irregularities that occur in the process of proving terrorism criminal acts, especially electronic evidence (Law Number 15 of 2003).

\section{Method}

2.1. Criminal Case Resolution Process

The process of resolving criminal cases based on the applicable law in Indonesia is currently carried out in a criminal justice system. Criminal Justice System or Criminal Justice System has now become a term that shows the mechanism of action in combating crime by using a system approach.

The term criminal justice system according to Ramington and Ohlin as quoted by Romli Atmasasmita is as follows:

Criminal justice system can be interpreted as the use of a system approach to the criminal justice administration mechanism, and criminal justice as a system is the result of interaction between laws and regulations, administrative practices and social attitudes or behavior. Understanding the system itself contains the implications of an interaction process that is prepared rationally and efficiently to provide certain results with all its limitations

The criminal justice system is a crime control system consisting of police, prosecutors, courts, and correctional institutions. Based on what Marjono stated, it can be seen that the components or sub-systems in the criminal justice system are the police, prosecutors, courts and correctional institutions.

The purpose of the criminal justice system is to prevent people from becoming victims of crime, to resolve cases of crimes that occur so that people are satisfied that justice has been upheld and the guilty persons are tried, to 
ensure that those who have committed crimes no longer repeat their actions.

Muladi stated that the criminal justice system is a network of justice that uses material criminal law, formal criminal law and criminal law. But these institutions must be seen in a social context. This is intended to achieve justice in accordance with what is aspired by the community.

According to Romli Atmasasmita, with the enactment of law No. 8 knew 1981 about criminal Procedure, making the Indonesian criminal justice system adhere to the accumulator system and was affected by the Due process model. The concept of the Due Process model strongly upholds the rule of law, in criminal cases no one is located and puts himself above the law. The accumulator system is a system that emphasizes proof with witnesses and concrete evidence (Romli Atmasasmita, 2010).

The concept of the Due process model strongly upholds the principle of Presumption of innocence. According to this concept every examination at the level of investigation, prosecution, and examination at a court hearing must follow formal procedures as determined by law. As for the values underlying this model's due process are:

a. Prioritizing formal adjudicative and adversary fact-finding. This means that a suspect must be brought before an impartial court and examined after the suspect has only obtained it in full to make a defense

b. Emphasis on prevention and eliminates as far as possible the errors of the judicial administration mechanism.

c. The judicial process must be controlled so that its use can be prevented from reaching its optimum point because power tends to be abused or chooses the potential to place individuals in the coercive power of the State.

d. Upholding the legal audit doctrine, namely:

1) A person is considered guilty if the determination of his mistake was carried out procedurally and was carried out by those who had the authority to do so.
2) A person cannot be considered guilty even though the reality will be burdensome if the legal protection given by the law to the person concerned is not effective in determining someone's guilt can only be done by an impartial court

3) The idea of equality before the law takes precedence. Prioritizing decency and the use of criminal sanctions (Romli Atmasasmita, 2010).

\subsection{Evidence in Criminal Matters Settlement}

Verification system consists of two words, namely the word "system" and "proof". Etymologically, the word "system" is the result of the adoption of the foreign word "system" (English) or "systemata" (Greek) to mean "an entity that is arranged in an integrated manner between the parts completeness with significant purpose definitely" or " a set of components that work together to achieve a certain goal ".

Proof is one of a series in the judiciary that plays an important role. This is caused by proving whether someone is guilty or not. If the evidence presented in court is inadequate or does not meet the requirements, the suspect will be released. However, if the evidence submitted is sufficient, the suspect can be found guilty. Therefore the verification process is an important process so that the guilty person is not released because of insufficient evidence. Or even innocent people are found guilty

The system of proof between countries is certainly different. This is usually adjusted to the culture or understanding adopted by the country. In general, the evidentiary system in a country is distinguished based on a state that adopts civil law and a state that adopts a common law. It is also based on several theories of proof systems. In his theory, the evidence system can be divided into four theories, namely the theory of proof system based on the Act positively, based on the judge's beliefs only, based on the judge's beliefs supported by logical reasons, and based on negative laws. Observed from the perspective of criminal law science, there are known (three) theories about the burden of proof, namely: 
a. Burden of Proof on Public Prosecutors The public prosecutor does not have the right to refuse the rights granted by law to the defendant, but that does not mean that the public prosecutor does not have the right to judge from the point of view of the public prosecutor in his requisitor.

The logical consequence of this burden of proof theory is that the Public Prosecutor must prepare evidence and evidence accurately, because if not, it will be difficult to convince the judge of the accused's guilt. The logical consequence of the burden of proof is on the Public Prosecutor correlating the presumption of innocence and the actualization of the principle of not blaming oneself. The burden of proof is known in Indonesia, that the provisions of Article 66 of the Criminal Procedure Code clearly state that, "the suspect or defendant is not burdened with the obligation of proof". The burden of proof like this can be categorized as "ordinary" or "conventional" proof of burden.

b. Burden of Proof on the Defendant

The defendant played an active role stating that he was not a criminal. Therefore, the defendant before a court hearing will prepare all the burden of proof and if he cannot prove it, the defendant is found guilty of committing a crime. In principle, the theory of reverse load (Shifting Burden of Proof) is called the theory of "Reversal Burden of Proof" (Omkering van het Bewijslast or Reversal Burden of Proof / Onus of Proof ").

In essence the meaning of the Reversal Burden of Proof and Shifting Burden of Proof is different. If Shifting Burden of Proof is interpreted as "Burden of Proof Burden" then the Burden of Proof Reversal is interpreted as "Burden of Proof Burden". The difference between the two meanings, if the shifting burden of proof is generally applied as a reversal of the burden of proof that is limited or impure, whereas in the reversal burden of proof uses a reversal of the burden of proof that is pure or absolute according to the term Indriyanto Seno Adji "Total Reversal Burden of Proof or Absolute ".Judging from the theoretical and practical perspectives of the burden of proof the theory can be classified again into a reversal of the burden of proof that is both pure and limited (limited burden of proof).

c. Burden of Proof Balanced

Concretizing this principle, both the Public Prosecutor and defendant and / or their Legal Counsel prove each other before the trial. Normally the Public Prosecutor will prove the guilt of the defendant while the defendant and his legal counsel will prove otherwise that the defendant is not legally proven and convincingly guilty of committing the criminal act charged. The principle of burden of proof is also called the principle of reversal of the burden of proof "balanced".

In the State of Indonesia, the burden of proof used is the burden of proof of general or conventional where the burden of proof lies with the Public Prosecutor. We can see that in Article 66 of the Criminal Procedure Code, the contents of which are "Suspect or Defendant not burdened with the obligation of proof". However, in certain criminal acts (such as corruption), the burden of reverse evidence is limited as contained in Article 37 paragraph (1) of Law no. 20 of 2001 whose contents "The defendant has the right to prove that he did not commit criminal acts of corruption". The intention is limited that the defendant has the right to prove before the court, but the Public Prosecutor must prove why to bring the indictment to court.

The evidentiary law in our criminal procedure law since the entry into force of the Herzeine Indonesisch Reglement (HIR), which is now called the Criminal Procedure Code, adheres to a system of proof according to the law in a limited way (negtief wettelijk bewisjstheorie). Article 183 Criminal Procedure Code, which reads:

"Judges must not convict a person unless if with at least two legal pieces of evidence he gains the conviction that a criminal act actually occurred and that the 
defendant is guilty of committing it."The formulation of Article 183 of the Criminal Procedure Code is considered more perfect because it clearly determines how many pieces of evidence the judge must use to obtain conviction and convict a criminal. The negative verification system in the Criminal Procedure Code is considered better and better guarantees legal certainty.

In the negative verification system adopted by Indonesia - as its essence, which is formulated in Article 183 of the Criminal Procedure Code, it can be concluded that the main points are:

a. The ultimate goal of proof is to decide upon a criminal case, which if it meets the evidentiary requirements can drop the criminal.

b. Terms of the results of evidence to convict.

In fact, the evidence is carried out to decide upon cases in casu criminal cases, and not merely to drop criminal cases. Because, to impose a criminal sentence, the defendant's guilty of criminal action is still needed.

Basically, the evidence is carried out in an effort to achieve the highest degree of justice and legal certainty in a judge's decision. Proof carried out to decide on a proven case or not in accordance with what has been indicted by the Public Prosecutor. There are two conditions for achieving an evidentiary result in order to convict a criminal. These two conditions are interrelated and inseparable.

First, the judge must use a minimum of two valid pieces of evidence. These two pieces of evidence do not have to be of different types. So it could consist of the same two pieces of evidence, for example the statements of two witnesses.

Second is that judges gain confidence. This judge's conviction must be formed on facts obtained from the evidence mentioned in the first condition, which has been determined by the Criminal Procedure Code. Judges' beliefs fall into the scope of the evidentiary activities if the evidentiary activities are not only seen as proof but to achieve the ultimate goal of the settlement of a criminal case that is to withdraw the verdict by the judge. Adami Chazawi in his book explains there are three judges beliefs that are absolute, level and can not be separated:

1. The belief that there has been a criminal offense according to the indictment Public Prosecutor (Prosecutor). In practice in court, stated that the offenses charged by the prosecutor proven legally and convincingly. What is meant by legitimate is eligible to use two or more items of evidence. But the conviction on the evidence of a criminal offense is not enough to convict the accused.

2. The belief that the defendant who committed the crime. Judges must gain confidence that the correct defendant had committed the crime of the public prosecutor indicted him. This belief is not enough to convict the defendant.

3. The belief that the offenses committed by the accused was to blame him. There are two things that can make a defendant is not convicted that there is justification and forgiving him. In the absence of these two reasons in themselves the defendant, the judge can gain confidence that the defendant can be blamed for their actions and can be dropped criminal. If the judge does not meperoleh confidence at this level, it means that the judge did not believe the defendant to blame for the crime of his accomplishments. Then the criminal will not be imposed but rather dropped the release of all charges.

Wirjono Prodjodikoro argues: "That negative verification system should be maintained for two reasons, namely the first, it is appropriate there should be a judge's conviction of the defendant's guilt can impose a criminal penalty. Do not be forced to convict the judge while judges are unsure of the guilt of the accused. Both are worthwhile if there are rules that bind judges in formulating his belief, that there are certain standards that must be followed by judges in doing justice"(Ronaldo Ipakit, 2015).

\subsection{Evidence}

In the Criminal Procedure Code has been set on the tools valid evidence that can be submitted before the trial court. Proof of 
evidence outside the Criminal Procedure Code considered to have no value and does not have the binding force.

As for the legal evidences according to the law, it has been regulated in Article 184 paragraph (1) of the Criminal Procedure Code as follows

a. Witness Statement;

b. Expert statement;

c. Letter;

d. Hints;

e. Defendant's statement.

\subsection{Electronic Evidence}

Age has begun to change. Rapid development of information technology and a lot of legal relations established through the internet media. Criminal cases begin to occur in cyberspace. When a case in cyberspace is brought to court it is almost certain that criminal acts in cyberspace (cyber crime) cannot be proven because there is no legal evidence according to the law.

Therefore, Law Number 11 of 2008 concerning Electronic Information and Transactions was born. In this law, the types of evidence are expanded. In Article 5 of Law 11 of 2008 explained as follows:

(1) Electronic Information and / or Electronic Document and / or prints with a valid legal evidence

(2) Electronic Information and / or Electronic Document and / or prints as referred to in paragraph (1) is an extension of the valid evidence in accordance with the Law of Procedure applicable in Indonesia.

Of the Articles above, expressly stated that the electronic information and / or electronic documents and / or the printout is a valid legal evidence and is an extension of the evidence contained in the Criminal Procedure Code. This Article is used to accommodate the needs of the evidence in the case of cyber crime.

Actually, prior to the enactment of Law 11 of 2008, the recognition of electronic data seagai evidence already exists in Indonesia. However, the use of electronic evidence can only be used on any particular criminal acts such as terrorism, corruption, and money laundering (Melani, Disemadi Silk Day, Nyoman United Putra Jaya, 2020)

\subsection{Criminal Acts of Terrorism}

Treaty on Cooperation among the State Members of the Commonwealth of Independent States in Combating Terrorism (1999); terrorism is an illegal act that is punishable under criminal penalties carried out with the aim of damaging public safety, influencing policy making by the authorities or monetary residents, and taking the form of violence or threats (Abdul Wahid, 2004).

According to Article 1 Perpu No.01 of 2002 concerning the Eradication of the Criminal Acts of Terrorism (now Law No.15 of 2003 concerning the Eradication of the Criminal Acts of Terrorism); terrorism is a systematic act against the law with a view to destroying the sovereignty of the nation and state by endangering the body, lives, morals, property and independence of people or causing general damage or atmosphere of terror or fear of people in a widespread manner so that destruction of objects occurs strategic vital, basic needs of the people, environment, morals, civilization, state secrets, culture, education, economy, technology, industry, public facilities or international facilities ( $T$. Nasrallah, 2008).

Terrorism according to the Big Indonesian Dictionary is to use violence to cause fear, in an effort to achieve a goal (especially political goals). Terrorists are people who use violence to cause fear (usually for political purposes). Terror is an arbitrary, cruel, cruel act and attempts to create fear, horror by a person or group. Terrorism is roughly a term used to use violence against civilians to achieve political goals, on a smaller scale than war.

Terrorism means 'to frighten'. The word comes from the latinterrere language, "causes fear", and is used generally in political terms as an attack on the civil order during the terror regime during the French Revolution at the end of the XVII century.

The use of the term terrorism seems to have experienced an expansion of meaning, because the community considers terrorism as acts of public destruction, carried out 
without a clear military reason, as well as the widespread spread of fear in the fabric of people's lives. Clearly the crime of terrorism is the result of the accumulation of several factors, not only by psychological factors but also economic, political, religious, sociological and many others (I Made Wirawan, Oheo K. Haris, Handdrawan, 2020)

\section{Results and Discussion}

\subsection{Strength of Evidence Electronic Evidence In Law Enforcement Terrorism In Indonesia}

Law Number 11 Year 2008 concerning Information and Electronic Transactions ("ITE Law") provides a legal basis regarding the legal strength of electronic evidence and the formal requirements and material of electronic evidence to be accepted at court. Electronic Evidence is Electronic Information and / or Electronic Documents that meet the formal requirements and material requirements stipulated in the ITE Law. Article 5 paragraph (1) of the ITE Law stipulates that Electronic Information and / or Electronic Documents and / or printouts are valid legal evidence. Electronic Information is one or a collection of electronic data, including but not limited to text, sound, images, maps , designs, photos, electronic data interchange (EDI), electronic mail, telegram, telex, telecopy or the like, letters, signs, numbers, Access Codes, symbols, or processed perforations that have meaning or can be understood by people who are able to understand it. (Article 1 point 1 of the ITE Law).

Electronic Documents are any Electronic Information that is created, transmitted, sent, received, or stored in analog, digital, electromagnetic, optical, or the like, which can be seen, displayed and / or heard through a Computer or Electronic System, including but not limited in writing, sound, pictures, maps, designs, photographs or the like, letters, signs, numbers, Access Codes, symbols or perforations that have meaning or meaning or can be understood by people who are able to understand it. (Article 1 point 4 of the ITE Law). In principle, Electronic Information can be distinguished but cannot be separated with Electronic Documents. Electronic Information is data or data collection in various forms, while Electronic Documents are containers or 'packets' of Electronic Information. For example, when we talk about music files in mp3 format, all information or music that comes out of the file is Electronic Information, while the Electronic Document from the file is $\mathrm{mp} 3$. Article 5 paragraph (1) of the ITE Law can be grouped into two parts. First Electronic Information and / or Electronic Documents. Second, printouts from Electronic Information and / or prints from Electronic Documents. Electronic Information and Electronic Documents which will become Electronic Evidence. While the printout of Electronic Information and Electronic Documents will be evidence of letters (Richard Totty, Anthony Hardcastle, 2003).

Article 5 paragraph (2) of the ITE Law stipulates that Electronic Information and / or Electronic Documents and / or printouts thereof are extensions of legal legal evidence in accordance with the applicable procedural law in Indonesia. The expansion here must be related to the type of evidence provided for in Article 5 paragraph (1) of the ITE Law. Expansion here means.

Adding evidence that has been regulated in criminal procedure law in Indonesia, for example KUHAP. Electronic Information and / or Electronic Documents as Electronic Evidence adds to the type of evidence provided for in the Criminal Procedure Code; Expanding the scope of evidence that has been regulated in criminal procedure law in Indonesia, for example in the Criminal Procedure Code. The printout of Electronic Information or Documents is evidence of letters regulated in the Criminal Procedure Code.

The expansion of the evidence set out in the Criminal Procedure Code has actually been arranged in various legislation in a scattered manner. For example the Company Document Law, the Terrorism Act, the Corruption Eradication Act, the Law on Money Laundering. The ITE Law confirms that in all applicable procedural law in Indonesia, Electronic Information and Documents and printouts can be used as legal evidence (Andi Hamzah, 1987). 
Physical evidence, whether exhibited in court or only below to be shown to judges in court. The longer, more and more models, including the use of hidden camera recordings, image recordings, video recordings that are hidden or deliberately made through image recording devices, video or sound. Like it or not, the court must be able to accept such evidence as evidence in court, especially in criminal acts of terrorism, with certain limitations, both with the help of expert witnesses and without expert witnesses, it is not wrong to consider its use as evidence in court.

Video can be used as evidence or can provide strength of proof with arguments for mistaken identity or reasoned matters. All videos must be relevant to the real situation. To get an authenticification of a video, the video must explain how the video was made that the video is viewed in a personal, clear and accurate way that clearly illustrates what is happening about a crime. The existence of a videotape that is suspected of criminal activity brings several legal issues at trial (Edmon Makarim, 2005).

\subsection{Implementation arrangements Electronic Evidence In Law Enforcement Terrorism In Indonesia}

Information and communication technology has changed the behavior of people and human civilization globally, in addition to the development of information technology has led to a world without borders.

At present a new legal regime has been born which is known as cyber law from the term Cyber law, a law related to the use of Information Technology with advances in technology, so the level of criminal acts will increase not only in daily life, but in cyberspace (Cyber crime) .

One of the problems that is often heard at this time in the life of the community is the crime of terrorism related to jihad and bombs, the problem of the crime of terrorism is the dissatisfaction with an ideology by wanting to implement a regime that they hold (Trisno Raharjo, 2011).

A criminal act (strafbaar feit) is formally considered an act that violates the law,
Indonesia is known as the State based on the law, then the law functions for the benefit of humans, both individual, community and state interests, the law regulates the relationship between one another by regulating restriction.

Prevention of handling terrorist criminal acts in cyberspace requires legislation that is not related to other laws and regulations by taking into account the hierarchy of the laws and regulations in order to achieve legal certainty, with legal actions such as a repressive which is divided into 3 things namely

1) A technological approach

2) religious approach and

3) Legal approach to achieve certainty and justice.

This electronic evidence can be the result of communication and information technology by means of the internet (Hi Tech Online), or it can also be the result of conventional electronic products, such as sound recorded through an ordinary "tape recorder". This article is still a rubber article which can be interpreted from various points of view, because it does not specifically mention electronic evidence based on the results of criminal acts based on information technology (cyber crime) regulated in Articles 183 and 184 of the Criminal Procedure Code (KUHAP) .

Specific provisions concerning the protection of the rights of suspects or defendants, this provision is a new legal institution in the Criminal Procedure Code called "hearing" and serves as an institution that conducts "legal audits" of all documents or intelligence reports submitted by investigators who determine whether or not to proceed. an investigation into alleged acts of terrorism.

On the other hand, the Law on the Eradication of Terrorism Acts contains provisions that allow the President to establish an anti-terror task force from the Police, TNI, which is based on the principle of transparency and public accountability and the principle of effective time eradication in order to avoid abuse of authority possessed by the task force. 
In the case of acts of terror on the internet, law enforcers can apply the Law No. 15 of 2003 concerning Establishment of Government Regulations in lieu of Law No. 1 of 2002 concerning Eradication of Terrorism Criminal Acts into Laws, as well as Law Number. 11 of 2008 concerning Information and Electronic Transactions (UU ITE), so that law enforcement can be done more effectively and efficiently.

Our legislation has recognized the existence of electronic evidence, although its position is still very low (cannot stand alone) when compared with the evidence in article 184 of the Criminal Procedure Code. There are already rules regarding the use of digital evidence in the form of websites in positive law in Indonesia, especially those governing the provisions of the Criminal Procedure Code. Synchronization of website evidence in Law No. 15 of 2003 with the Criminal Procedure Code very clearly seen, this can be found in Article 27 of Law Number 15 of 2003 paragraph (1) and also introduces a new evidence in the criminal procedure code (Dellyana, Shant, 1988).

The use of evidence in the form of eavesdroppers and video footage has actually been applied in the 2002 Bali Bombing case. In using this evidence the investigator referred to article 27 of the Government Regulation in lieu of the Law of the Republic of Indonesia No.1 of 2002 concerning the eradication of criminal acts of terrorism. Although inviting controversy, the prosecutor insisted that the reading of witness statements from Malaysia and Singapore that could not be present at the trial was valid because it was in accordance with the description of the evidence in the law (Richard Totty dan Anthony Hardcastle, 2003).

\section{Conclusion}

1. The strength of proof of electronic evidence in law enforcement of criminal acts of terrorism in Indonesia is Law Number 11 of 2008 concerning Electronic Information and Transactions ("ITE Law") provides a legal basis regarding the legal force of electronic evidence and the formal and material requirements of evidence electronic to be accepted at court. Electronic Evidence is Electronic
Information and / or Electronic Documents that meet the formal requirements and material requirements stipulated in the ITE Law. Article 5 paragraph (1) of the ITE Law stipulates that Electronic Information and / or Electronic Documents and / or printouts are valid legal evidence.

2. Implementation of the regulation of electronic evidence in law enforcement of criminal acts of terrorism in Indonesia is the use of evidence in the form of wiretaps and video recordings which have actually been applied in the Bali Bombing I case, 2002 ago. In using this evidence the investigator referred to article 27 of the Government Regulation in lieu of the Law of the Republic of Indonesia No.1 of 2002 concerning the eradication of criminal acts of terrorism. Although inviting controversy, the prosecutor insisted that the reading of witness statements from Malaysia and Singapore that could not be present at the trial was valid because it was in accordance with the description of the evidence in the law. The same thing is regulated in the Law on Information and Electronic Transactions. Article 5 states that electronic information and / or printouts of electronic information are legal evidence and have legal legal consequences. Of course, electronic information is declared valid when using an electronic system in accordance with applicable laws and regulations.

\section{References}

Alan M. Gahtan, Electronic Evidence, Ontario, Carswell, 1999

Abdul Wahid, Terrorism Crimes, PT. Retika Aditama, Bandung, 2004.

Andi Hamzah, Introduction to Indonesian Criminal Procedure Law. Ghalia Indonesia, Jakarta, 1987.

Dellyana, Shant. 1988, Concept of Law Enforcement. Liberty, Yogyakarta, 1988.

Edmon Makarim, Introduction to Telematics Law: A Compilation of Studies, PT Raja Grafindo Persada, Jakarta, 2005.

Hadi al-Madkhaly, Terrorism in Islamic Review, Maktabah Salafy Press, Tegal, 2002. 
Hermawan Sulistyo, Beyond Terorism, Pustaka Sinar Harapan, Jakarta, 2002.

Muladi, Democracy of Human Rights and Legal Reform in Indonesia, Habibie Center, Jakarta, 2002.

Richard Totty and Anthony Hardcastle, Computer Related Crime, George Washington University Law School, Vol. 78, No. 4, November 2003.

Romli Atmasasmita, Contemporary Criminal Justice System, Kencana Prenada Media Group, Jakarta, 2010.

S.R. Sianturi, "Principles of Criminal Law in Indonesia and Its Application", Mandar Maju, Bandung, 1998.

T. Nasrullah, At a glance, Juridical Review of Both the Material and Formal Legal Aspects of Law No. 15/2003 Concerning Eradication of Terrorism, Paper At the Seminar and Workshop on "State Security" organized by the Indonesian Police Watch in Jakarta Metropolitan Police, Tuesday, March 29, 2008.

Trisno Raharjo, Criminal Mediation in the Criminal Justice System: A Comparative Study and Its Application in Indonesia, Litera Book, Jogjakarta, 2011

Wirjono Prodjodikoro, Criminal Procedure Law in Indonesia, Bandung Well, Bandung, 1997

Law number 15 of 2003 concerning eradicating acts of terrorism

Law Number 11 Year 2008 concerning Information and Electronic Transactions

Law Number 2 of 2002 concerning the Indonesian National Police

RI Law No. 8 of 1981 concerning Criminal Procedure Code 